\title{
Model Development Of Islamic Education Improvement Program By Baznas In Tanah Datar Regency
}

\author{
Yasmansyah $^{1)}$, Iswantir ${ }^{2)}$ \\ 1,2) S3 Program studi PAI FTIK IAIN Bukittinggi \\ *Coresponding Author \\ Email : yasmansyahsagmpd@gmail.com
}

\begin{abstract}
Indonesia is a country with the largest Muslim population in the world. The potential of Muslim funds collected from zakat, infaq and shadaqah is an alternative solution that can be utilized to overcome the problem of poverty and social inequality in Indonesia. This article discusses how the Development Model of the Islamic Religious Education Improvement Program by BAZNAS Tanah Datar Regency. The type of research used in this article is qualitative with the research method used is descriptive method, namely the problem method that guides researchers to explore and or photograph the situation to be studied thoroughly, broadly and deeply. In addition, this research is also library research. the sources of data obtained through literacy in the form of books, journal articles and other writings concerning the institution and the subject of this writing. From the results of the study, it can be concluded that BAZNAS Tanah Datar as an institution authorized to manage zakat funds has distributed zakat funds in one program called the Education program which is given in two stages with a total number of 5785 people both at the elementary, junior high school to university level. As well as in the distribution of educational assistance, mentoring is carried out by parents, teachers and the school who coordinates the assistance to be provided so that it can be managed as well as possible by the school, so that the goals and objectives of zakat can be achieved.
\end{abstract}

Keywords: Development Model, Islamic Religious Education, BAZNAS Tanah Datar

\section{INTRODUCTION}

Indonesia is a country with the largest Muslim population in the world. The potential of Muslim funds collected from zakat, infaq and shadaqah is an alternative solution that can be utilized for efforts to overcome the problem of poverty in Indonesia which cannot be solved and is resolved only with State revenue budget (APBN), funds originating from tax revenues and foreign debt. In the practice of Islamic teachings, zakat has an important role as a supporting element for da'wah and community development. The purpose and wisdom of zakat as a religious institution is functionally related to efforts to solve problems of poverty and social inequality.

Zakat which is managed with a trustworthy, professional and integrated system and management with effective guidance and supervision from the government is expected to spur economic movement in society and nourish the social order so that the gap between groups of people who cannot afford it will be reduced. Therefore, the spirit that Islam wants to instill in all mankind through the teachings of zakat is the spirit to try and improve life to a better standard or can be simplified in the sentence of changing mustahik into muzakki through the multi-benefits of zakat.

For this reason, zakat utilization is directed as an instrument to build people's lives, including through utilization programs for basic needs, education financing, health service facilities and economic empowerment whose benefits do not run out instantly in the hands of mustahik. Advancing the general welfare and educating the nation's life is a constitutional 
mandate that must be realized by the state, the realization is carried out through education. Education is the most important thing in human life. Education is not just a transfer of knowledge but also the transfer of values with the transfer of knowledge and good values, enabling humans to become individuals who not only have intellectual intelligence, but also have moral intelligence. Allah SWT emphasizes the need for collaboration between science and faith to achieve a higher degree.

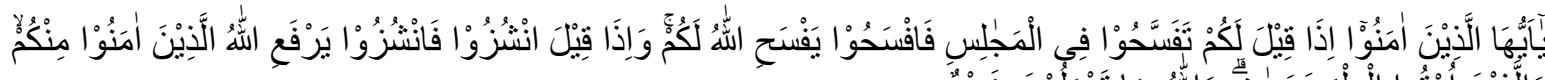

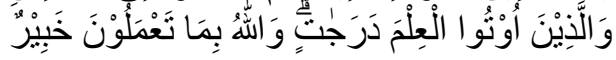

O you who have believed, when you are told, "Space yourselves" in assemblies, then make space; Allah will make space for you. And when you are told, "Arise," then arise; Allah will raise those who have believed among you and those who were given knowledge, by degrees. And Allah is Acquainted with what you do. (Q.s Al-Mujadillah:11)

From the verse above, it can be understood that between intellectual and spiritual intelligence achieve a unified whole in order to achieve a noble goal, the achievement of a high degree before Allah SWT. Basically, science is not enough to lead humans to become highly civilized creatures and have the highest degree before Allah SWT. So in the verse it can be clearly understood that to achieve a high degree, two components are needed, namely knowledge and the depth of one's faith. If these two components are already present in a person's soul, it is very possible that his degree will be glorified by Allah. Therefore, education is the key to the progress of a nation or region. Nations that have low quality education will fall behind and are left behind. Likewise, regions that have low quality and quality of education will automatically be left behind from areas that have more advanced quality of education. The level of education is one of the qualities of human capital. One of the factors that determine the formation of quality human resources is the education factor, therefore the problem of education must receive serious attention because it involves the future of the nation.

In its development, there are problems that hinder the level of education in Indonesia, including the problem of poverty and unemployment. Poverty is the result of the practice of economic policies that are not in accordance with the principle of balance, in other words, economic theory so far has not been able to optimally solve the problem of poverty and underdevelopment.

One solution to poverty alleviation is the zakat instrument. Zakat is one of the five strategic instrumental values and is very influential on the economic behavior of humans and society as well as economic development in general. The purpose of zakat is not only to support the poor consumptively but has a more permanent goal, namely alleviating poverty (Hafidhuddin, 2002). Zakat is i'badah maliyah ijtima'iyah which means worship in the field of property which has a very important and strategic position and position in building welfare and improving people's activities. This is of course if the collection and distribution is optimized in accordance with sharia provisions by a strong, trustworthy, transparent and potential amil zakat agency or institution (Yusuf, 2004).

Zakat as worship is maliya ijtima'iyyah and must be managed in a professional manner because professional management will increase the chances of improving services for the community in paying zakat in accordance with religious provisions. Moreover, zakat has a function and role in realizing social welfare and social injustice so that it can increase the results and efficiency of zakat. The management of zakat in Indonesia is carried out by the Amil Zakat Agency and the Amil Zakat Institution by receiving or taking zakat assets or goods from the muzakki on the basis of the muzakki notification. 
The enactment of Law Number 23 of 2011 concerning the management of zakat was followed by the issuance of Government Regulation of the Republic of Indonesia Number 14 of 2014 concerning the Implementation of Law Number 23 of 2011 concerning the management of zakat. This law was made to optimize the distribution of zakat which aims for economic equality and development of the people (Saifuddin, 2013: 2). The distribution of zakat is a consumptive zakat distribution activity and must be immediately distributed to mustahik in accordance with the priority scale that has been prepared in the work program whose purpose is to improve community welfare and alleviate poverty.

In the management of zakat, there is an institution that distributes zakat funds called the National Amil Zakat Agency. In Tanah Datar Regency itself, the Tanah Datar Regency National Amil Zakat Agency has been formed by the Tanah Datar Regency government through a Regent's Decree and is domiciled in the district capital. Since its establishment in 1999, BAZNAS Tanah Datar Regency has gone through several management periods. At first this institution was called BAZIS Then it changed its name to BAZ until finally it was called BAZNAS since 2011.

In managing zakat funds, the Baznas of Tanah Datar Regency is distributed in five forms of programs in accordance with the program plans that have been prepared and agreed upon. The five programs are economic, education, da'wah and advocacy, humanitarian, and health programs. These programs are synchronized with the needs, conditions of the community and local government programs whose objectives are to ease the workload of local governments, reduce poverty and socio-economic disparities and improve quality of life of the community through existing programs at BAZNAS Tanah Datar Regency.

From the description above, in the discussion of this article the author will discuss about "How the Development Model for the Improvement of Islamic Education Programs through the National Amil Zakat Agency of Tanah Datar Regency"

\section{RESEARCH METHODS}

This research belongs to the type of qualitative research with the research method used is descriptive method, namely the problem method that guides researchers to explore and or photograph the situation to be studied thoroughly, broadly and deeply. Qualitative research method is one of the research procedures that produces descriptive data in the form of speech or writing and the behavior of the people being observed. The qualitative approach is expected to be able to produce in-depth descriptions of speech, writing and or observable behavior from a particular individual, group, community and or organization in a particular context setting that is studied from a complete, comprehensive and holistic point of view.

In addition, this research is also a library research in which the data sources obtained through literacy are in the form of books, journal articles and other writings concerning the institution and the subject of this writing. While the primary data sources are obtained directly from the object of writing by in-depth interview method in-dept interview. For secondary data, data that does not directly provide data to researchers, for example, must go through other people or search through documents. 


\section{RESULTS AND DISCUSSION}

\section{The Concept of Zakat and Social Functions}

Zakat comes from the word zaka which means holy, good, blessed, growing and developing (Hafidhuddin, 2002). In language (lughat) zakat means blessing, growing (alnamaa), increasing or it can be interpreted to clean or purify. It is so named because zakat is a process of improving and cleaning oneself from what is obtained (Wibowo, 1996).

Meanwhile, according to syara' means surrendering part of the property to the rightful (mustahiqq) with certain conditions (Hakim, 2015). Then it is determined that people who have assets that have reached nișab (a certain amount +94 grams of gold) and aul (one full year of ownership), are obliged to give them in a certain level (2.5\% to $20 \%)$ to the person who is entitled to it (mustahiqq). The mustahiqq zakat consists of eight groups or așnaf, as the word of Allah SWT as follows:

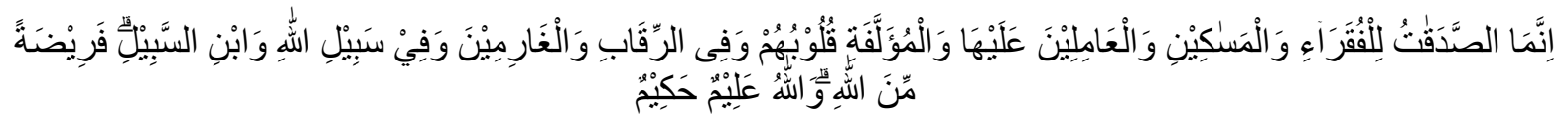

It means: "Zakah expenditures are only for the poor and for the needy and for those employed to collect [zakah] and for bringing hearts together [for Islam] and for freeing captives [or slaves] and for those in debt and for the cause of Allah and for the [stranded] traveler - an obligation [imposed] by Allah. And Allah is Knowing and Wise.." (Q.S At-Taubah:60).

The main function of zakat in a social context (ijtimā'iyyah), according to Marcel Boisard, a French Muslim, is to share with fellow believers the common wealth bestowed by Allah, with which solidarity and brotherhood will thrive (Marsel A. Boisard, 1981). In addition, zakat is also intended to prevent hoarding of assets. Roger Garaudy, a Western Muslim, explained that the obligation of zakat which is determined every year is to ensure that there is no accumulation of wealth for certain parties. If this system is implemented, then there will be no members of society who live as parasites to others, moreover live by endangering others, such as stealing and robbing (Garaudy, 1986).

In essence, zakat is expected to be a productive investment. Productivity does not only mean reward for the executor (muzakk), but also means that the assets that are handed over as zakat assets will continue to grow in the market and be useful for the empowerment of the people (mustahiqq). Islam teaches that property is not a goal in life, but is only a tool for exchanging benefits and meeting each other's needs, which are used to achieve social justice that Islam aspires to (Salamah, 1987).

According to Abd. Al-Rahim bin Salamah, in addition to cleansing the soul and property, is also a powerful means of distributing property in society. Zakat is what made Islamic countries rich and prosperous, which did not recognize poverty and suffering. In this connection zakat is a theoretical framework for establishing social justice in Islamic society. the needs of those who are needy, poor and shrouded in suffering. Zakat is also used to fight inflation and narrow the gap and even try to eliminate social stratification (Al-Tawati, 1986).

By facilitating citizens who are Muslim in paying zakat, the government not only gives freedom to citizens in practicing their religion and beliefs as stated in the 1945 Constitution of the Republic of Indonesia Article 29 paragraphs (1) and (2), but directly the government has accelerated the ideals of the nation to educate the nation's life as stated in the preamble. In easy-to-understand language, the problem of zakat is no longer only a problem for Muslims but 
has become a problem with the Indonesian people. The role of the government and society simultaneously is an acceleration for the realization of the mandate of the nation's founders, the education budget is 20 percent. support from the government, which is no less important is the issue of permissibility in religious law. Because in the Qur'an at-taubah verse 60 it is stated that there are 8 groups entitled to receive zakat without mentioning the name of education in it. Responding to the verse to allow zakat for education, the ulama' interpreted sabilillah with the meaning of sabiilil khoir (path for goodness), including for education.

\section{Model Development of Islamic Education Improvement Program}

Based on the agreement of the majority of Islamic scholars/intellectuals regarding the social function of zakat, a framework for empowering zakat was developed to finance education. The method commonly used is to distribute the zakat funds as a source of scholarships for underprivileged Muslim children. This method is commonly used by Amil Zakat Agencies/Institutions in Indonesia.

The empowerment of zakat in the success of education in Tanah Datar Regency has a very important role where with the empowerment of education zakat in Tanah Datar Regency it is increasingly possible to achieve national education goals. National education aims to educate the nation and develop Indonesian people as a whole, namely humans who believe and are devoted to God Almighty and have noble character, have knowledge and skills, physical and spiritual health, a solid and independent personality and a sense of social and national responsibility." (Ihsan, 2001)

For this reason, education is one of the programs of the Tanah Datar National Amil Zakat Agency (BAZNAS) in managing and distributing zakat. Human Resources through Education and this is in line with the existing program at BAZNAS Tanah Datar, through this program it is expected to be able to alleviate poverty and socio-economic imbalances in the community which is of course supported by the quality of human resources in the area.

In 2021 BAZNAS Tanah Datar Regency has distributed Zakat Funds for Education Programs through scholarships distributed to students ranging from Elementary School, Junior High School, and Senior high School to Universities with a total fund of Rp. 3,523,213,000, with the details of the students being assisted as follows:

a. For Elementary School (SD) there are 2,500 people in Phase one (1) and 600 people in Phase two (2) for a total of 3,100 people.

b. At the junior high school level, there are 2,000 people in stage one (1) and 500 people in stage two (2) for a total of 2,500 people

c. For the Higher Education level, there are 142 in the first stage (1) and 43 people in the second stage (2).

From the data above, it can be concluded that BAZNAS Tanah Datar has special attention in efforts to improve the quality of human resources of the people of Tanah Datar Regency by providing two-stage educational assistance and is committed to realizing the goals of National Education while still guided by Islamic teachings and regulations per law on how to manage good and right on target in managing the zakat funds.

The model for distributing zakat funds in the education sector is to provide educational assistance. The provision of education funds is in two ways, namely direct assistance funds in the form of money to help ease the burden on families whose children are continuing their education and indirectly providing funds, namely providing these funds directly to the school so that the funds are directly managed or regulated by the school. given according to the needs of recipients of educational aid funds so that the money that has been received by families who 
receive education aid funds can be more optimal in managing the money in carrying out their children's school needs.

The procedure used by BAZNAS Tanah Datar in the process of distributing zakat in the field of education is that prospective recipients of educational assistance funds must go to BAZNAS Tanah Datar by submitting an application for educational assistance funds, in this case the prospective recipient of aid funds must go through data collection, family conditions, and what school level the child is at. who are continuing their education after that the prospective recipient of the education fund can submit a family card, ID card, and a certificate of incapacity from the village head so that they are eligible for education assistance funds. Prospective recipients of education funds after collecting these requirements can be directly given to BAZNAS Tanah Datar to verify their eligibility to be given education aid funds.

This is in accordance with the word of Allah in Q.S. Al-Baqarah verse 273 as follows:

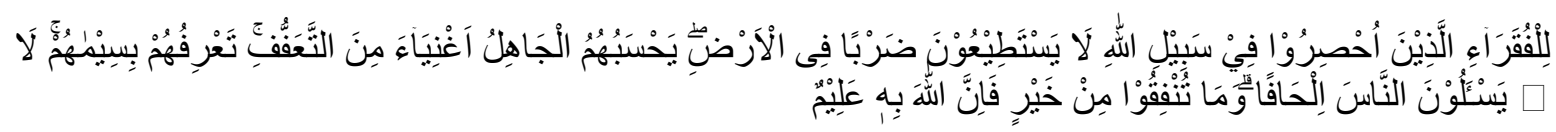

It means: " (Your spending and charity are) for the poor who are devoted themselves to the Way of Allah and cannot move about in the earth (gain their livelihood by making trade). The one who does not know them (their state) thinks that they are rich because of their chastity; you can recognize them by their mark; they do not beg from others importunately; and whatever you spend in good, surely Allah knows it well.." (Surah al-Baqarah (2): 273).

The verse above explains that that is a picture of poor people who decide to emigrate to Allah and His Messenger. They do not have property and business, then zakat, infaq and sadaqah aid funds are given to those who are fulfilling productive needs such as education. This shows that the distribution of zakat has goals and objectives. The target here is the parties who are entitled to receive zakat, while the aim is to increase welfare in the economic and educational fields so that it can reduce the underprivileged groups of people and in the end will increase the muzakki group.

From the explanation above, it can be concluded that in improving the Islamic education program through Zakat in Tanah Datar Regency, it can be concluded that in the distribution of zakat funds through the education sector it can be understood that as follows:

1. Lighten the burden of life

Zakat is a help for people who are poor and people who need financial assistance. Zakat given to the poor can help ease the economic burden they face. Zakat funds can be used to fulfill their life needs, both material needs and spiritual needs. .

2. Increase Learning Motivation

The level of students' awareness of the needs that drive their behavior/deeds and their awareness of the learning objectives to be achieved, and the teacher's attitude towards the class, namely the teacher must act in a clear and meaningful direction. It is the same with the distribution of zakat infaq and shadaqah in the education sector, whose role is assistance from the school so that parents and guardians do not worry about the learning process and funding assistance that has been provided by BAZNAS Sidoarjo. It can be concluded that the existence of educational funding assistance can provide learning motivation for children who receive educational funding assistance and from the school which is mandated by Baznas has been running optimally. 


\section{Improve well-being}

The distribution of zakat is able to have a positive impact on poverty alleviation programs and the welfare of the poor. In addition, it is also used as a parameter to determine a person's welfare status. The well-being of a society depends on the disbursement and maintenance of five basic goals, namely: religion, life or soul, family or lineage, property, and reason

\section{CONCLUSION}

From the description above, it can be concluded that one solution to poverty alleviation is the zakat instrument. Zakat is one of the five strategic instrumental values and is very influential on the economic behavior of humans and society as well as economic development in general. The purpose of zakat is not only to support the poor consumptively but has a more permanent goal, namely alleviating poverty. Through education, humans will have many skills and personalities. Education is not only a transfer of knowledge but also the transfer of values with the transfer of knowledge and good values, enabling humans to become individuals who not only have intellectual intelligence, but also have moral intelligence.

In developing a model for improving the Islamic Religious Education program through the Tanah Datar National Amil Zakat Agency, it is clear that BAZNAS Tanah Datar has distributed zakat funds in one program called the Education program which in the distribution process pays attention to the eight asnaf by way of students submitting applications to Baznas Tanah Datar by bringing requirements such as family card, identity card certificate of incapacity and then submits it to the institution for a feasibility survey process to determine whether the person concerned is worthy of receiving zakat funds based on the eight asnaf. As well as in the distribution of educational assistance, mentoring is carried out by parents, teachers and the school who coordinates the assistance to be provided so that it can be managed as well as possible by the school, so that the goals and objectives of zakat can be achieved.

\section{REFERENCES}

Abd Al-Karim Al-Tawati, Mafhum Al-Zakah wa Ab'aduhā wa Hikmatu Tashrī'ihā fī al-Islām, dalam AlManhal vol. 447 (1986).

Abd. Al-Rahim bin Salamah, Al-Siyāsah al-Māliyah fī al-Islām, dalam Al-Manhal vol. 447 (1987).

Adnan Abubakar, Pemberdayaan Zakat Untuk Pendidikan, Jurnal Nur El-Islam, Volume 2 Nomor 1, 2015.

Ali Muchsan, Peranan Pemberdayaan Zakat dalam Meningkatkan Pendidikan di Desa Kuwik Kecamatan Kunjang, Jurnal Inovatif Volume 1 Nomor 2, 2015.

Arif Rahman Hakim, dkk, 2014, Peran Zakat dalam Pembangunan Pendidikan di Kota Bogor, Jurnal Ekonomi Islam, Volume 5 Nomor 2.

Direktorat Pemberdayaan Zakat, 2006. Pedoman Zakat Seri 9, Jakarta: Ditjen Bimas Islam Depag RI.

Hafidhuddin, Didin. 2002. Zakat dalam Perekonomian Modern. Jakarta: Gema Insani Pres. 
Hakim, A. 2015, Pengelolaan Zakat Pertanian di Lazis Nu Kabupaten Kendal. Wahana Akademika, Volume 2 Nomor 2, Oktober.

Ihsan,Fuad dan Hamdani Ihsan. 2001. Filsafat Pendidikan Islam. Bandung: CV Pustaka Setia.

Kumoro W. Wibowo, 1996. Pemanfaatan Zakat, Jakarta: Isnet.

Kuntowijoyo, 1997.Paradigma Islam; Interpretasi untuk Aksi,Bandung: Mizan.

M. Asror Yusuf, 2006. Agama Sebagai Kritik Sosial, Yogyakarta: IRCISOD.

Mannan, M.A. Islamics Economics: Theory and Practice, Edisi Revisi, Houdder \& Stongton, Islamic Academy, Cambridge: July 1984.

Marsel A. Boisard, 1981. Humanisme dalam Islam, terj. H.M. Rasjidi, Jakarta: Bulan Bintang.

Roger Garaudy, 1986.Mencari Agama pada Abad XX; Wasiat Filsafat Roger Garaidy, terj. H.M. Rasjidi,Jakarta: Bulan Bintang.

Wibowo, A. 2015, Distribusi Zakat Dalam Bentuk Penyertaan Modal Bergulit Sebagai Accelerator Keserataan Kesejahteraan,Jurnal Ilmu Manajemen, Volume 12, Nomor 2 April.

Yusuf, Mohammad Asror. 2004. Kaya Karena Allah. Tangerang: PT Kawan Pustaka. 